US Army Corps

of Engineers ${ }_{\circledast}$

Engineer Research and

Development Center

Aquatic Plant Control Research Program (APCRP)

\title{
Biological Phosphorous Removal From Impacted Water
}

Carina M. Jung and Jed O. Eberly

August 2018
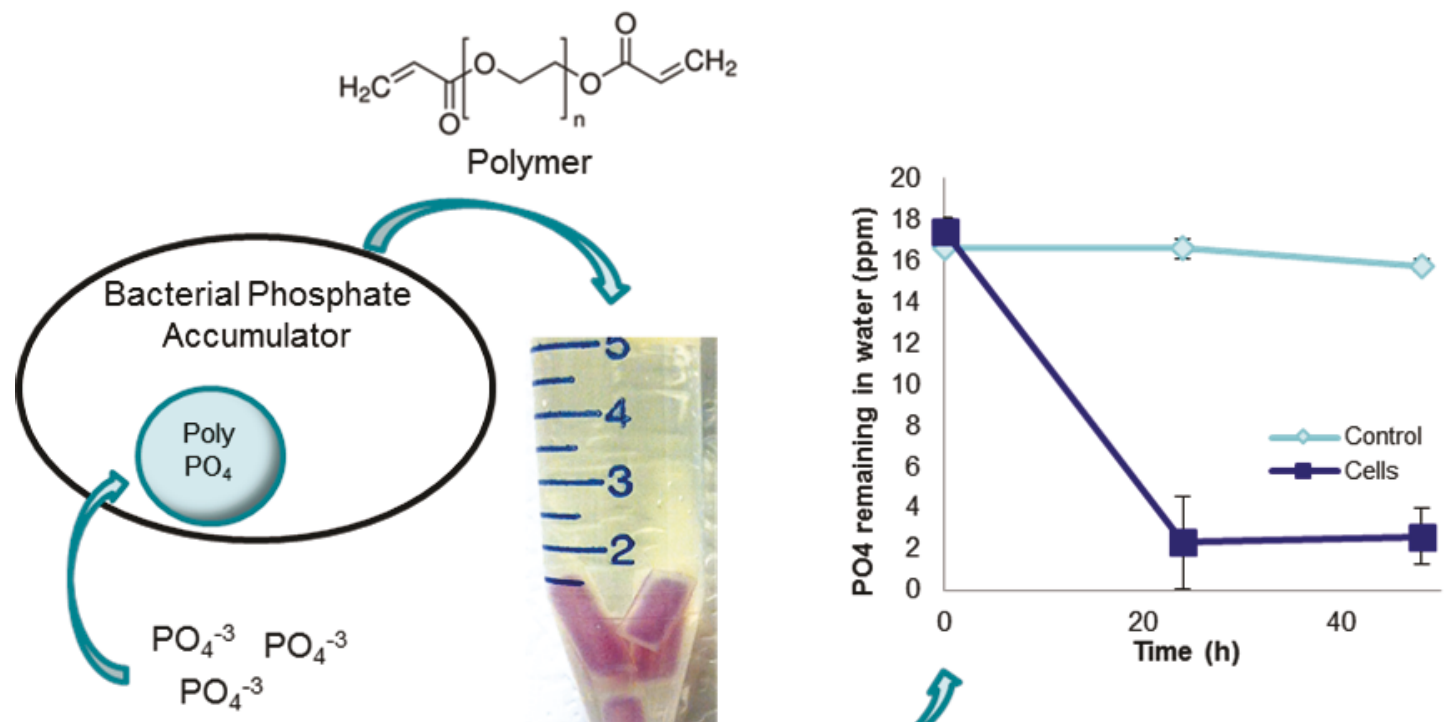

Polymer-immobilized

Bacteria 
The U.S. Army Engineer Research and Development Center (ERDC) solves the nation's toughest engineering and environmental challenges. ERDC develops innovative solutions in civil and military engineering, geospatial sciences, water resources, and environmental sciences for the Army, the Department of Defense, civilian agencies, and our nation's public good. Find out more at www.erdc.usace.army.mil.

To search for other technical reports published by ERDC, visit the ERDC online library at http://acwc.sdp.sirsi.net/client/default. 


\section{Biological Phosphorous Removal From Impacted Water}

Carina M. Jung and Jed O. Eberly

U.S. Army Engineer Research and Development Center (ERDC)

Environmental Laboratory

3909 Halls Ferry Road

Vicksburg, MS 39180-6199

Final Report

Approved for public release; distribution is unlimited.

Prepared for Headquarters, U.S. Army Corps of Engineers

Washington, DC 20314-1000

Under "Biological Phosphorous Removal from Impacted Water, Project Number 454747." 


\section{Abstract}

Nutrient input into waterways from agriculture runoff, sewage, and other sources is a major cause of water pollution and cultural eutrophication. Nitrogen and phosphate are growth-limiting nutrients, that when present in high concentrations, allow for unchecked growth of cyanobacteria, resulting in reduced water quality and the potential for proliferation of harmful algal blooms (HABs). Physical removal of these nutrients from waterways is needed. Immobilized phosphorous accumulating bacteria could be used as a phosphate biofilter to absorb and accumulate phosphate from impacted water. The research presented herein demonstrates the immobilization or encapsulation of phosphate accumulating bacteria in a silica sol-gel matrix that can be suspended in a high phosphate water system and then retrieved to collect excess phosphate $\left(\mathrm{PO}_{4}\right)$. Growth and $\mathrm{PO}_{4}$ uptake was monitored in free-living and sol gel immobilized, pure cultures of the phosphate hyperaccumulating bacterium Microlunatus phosphovorus. Phosphate was accumulated at a rate of 3.3 parts-per-million $(\mathrm{ppm}) \mathrm{PO}_{4} / \mathrm{h}(1.11 \mathrm{mmol} \mathrm{P} / \mathrm{h})$ and $80 \mathrm{mmol} \mathrm{P} / \mathrm{g}$ cell dry wt/h, respectively. Application of immobilized cells to phosphate impacted waters for uptake and removal of phosphate would allow for large-scale removal of phosphate, thus reducing the eutrophication effect and limiting the potential for HABs.

DISCLAIMER: The contents of this report are not to be used for advertising, publication, or promotional purposes. Citation of trade names does not constitute an official endorsement or approval of the use of such commercial products. All product names and trademarks cited are the property of their respective owners. The findings of this report are not to be construed as an official Department of the Army position unless so designated by other authorized documents. 


\section{Contents}

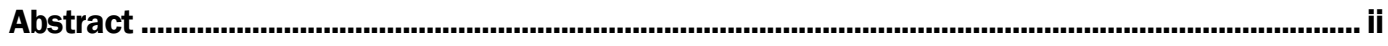

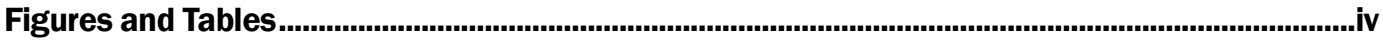

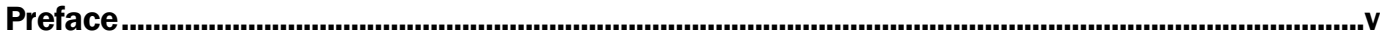

Unit Conversion Factors .................................................................................................................

Acronyms and Abbreviations .............................................................................................................vii

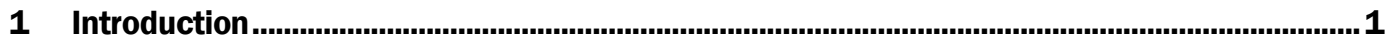

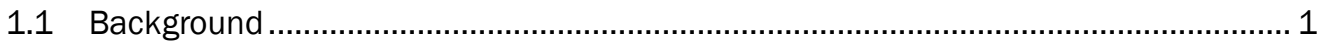

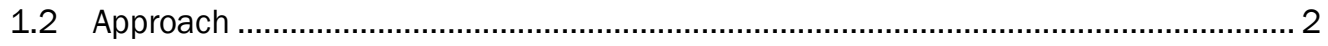

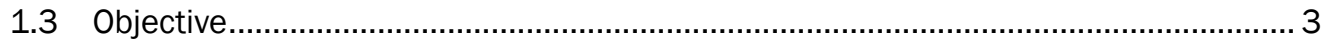

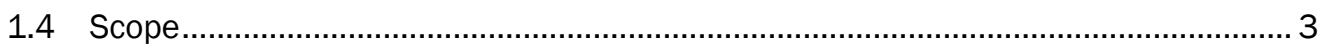

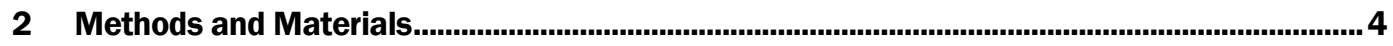

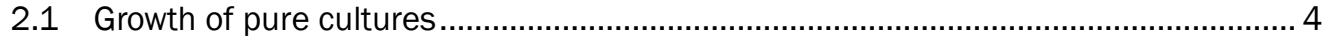

2.2 Monitoring of phosphate uptake.......................................................................... 4

2.3 Sol-gel encapsulation ..................................................................................... 4

2.4 Sol-gel washing trials ........................................................................................... 5

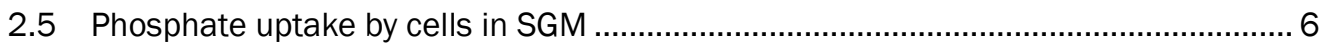

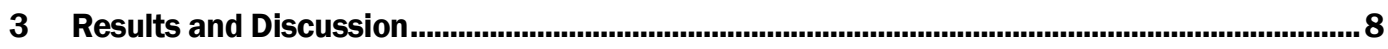

4 Conclusion .................................................................................................................................................13

References ...........................................................................................................................................14

\section{Report Documentation Page}




\section{Figures and Tables}

\section{Figures}

Figure 1. Outgrowth test to determine survival and escape of cells from the SGM in which they were embedded. Purple color indicates cell activity. 6

Figure 2. Protective plastic flow-through encasement for sol-gel embedded cells.............................. 7

Figure 3. Comparative growth of potential phosphate accumulating organisms over $116 \mathrm{~h}$............. 8

Figure 4. Phosphate uptake from growth medium of putative phosphate accumulating organisms over $116 \mathrm{~h}$

Figure 5. Sol-gel encapsulated M. phosphovorus cells in microplate wells. Purple color indicates metabolic activity.

Figure 6. Phosphorous uptake from ML medium with by sol-gel encapsulated $M$. phosphovorus cells in a sponge encasement. Individual replicates shown due to contamination of the medium with escaped cells. No-cell control SGM in sponge remained sterile (black, dashed line).

Figure 7. Phosphorous uptake from $\mathrm{ML}$ medium with no $\mathrm{PO}_{4}$ added by sol-gel encapsulated $M$. phosphovorus cells in a sponge encasement inside bioballs. No contamination was observed in the encapsulated cells (solid line) or the no-cell control (dashed line).

\section{Tables}

Table 1. Cell encapsulation formulation as determined empirically to preserve physiological activity and reduce escape of cells from the matrix (modified from Dickson and Ely 2011). 


\section{Preface}

This study was conducted for the U.S. Army Corps of Engineers - Engineer Research and Development Center (USACE-ERDC) Aquatic Plant Control Research Program (APCRP) initiated in FY2015, "Biological Phosphorous Removal from Impacted Water, Project Number 454747.”

The work was performed by the Environmental Processes Branch (EPP), Environmental Processes and Engineering Division (EPED), ERDC Environmental Laboratory (ERDC-EL). At the time of publication, Dr. Brandon Lafferty was Chief, CEERD-EPP; Mr. Warren Lorentz was Chief, CEERD-EPED; and Dr. Alfred Cofrancesco, was the Technical Director for Environmental Engineering and Sciences, Civil Works. The Deputy Director of ERDC-EL was Dr. Jack Davis and the Director was Dr. Ilker R. Adiguzel.

COL Ivan P. Beckman was the Commander of ERDC, and Dr. David W. Pittman was the ERDC Director. 


\section{Unit Conversion Factors}

\begin{tabular}{|l|l|l|}
\hline Multiply & By & To Obtain \\
\hline degrees Fahrenheit & $(\mathrm{F}-32) / 1.8$ & degrees Celsius \\
\hline feet & 0.3048 & meters \\
\hline inches & 0.0254 & meters \\
\hline inch-pounds (force) & 0.1129848 & newton meters \\
\hline microinches & 0.0254 & micrometers \\
\hline ounces (U.S. fluid) & $2.957353 \mathrm{E}-05$ & cubic meters \\
\hline pints (U.S. liquid) & 0.473176 & liters \\
\hline quarts (U.S. liquid) & $9.463529 \mathrm{E}-04$ & cubic meters \\
\hline square inches & $6.4516 \mathrm{E}-04$ & square meters \\
\hline
\end{tabular}




\section{Acronyms and Abbreviations}

\begin{tabular}{ll} 
APCRP & Aquatic Plant Control Research Program \\
ATP & adenosine triphosphate \\
DoD & Department of Defense \\
EL & Environmental Laboratory \\
EPP & Environmental Processes Branch \\
EPED & Environmental Processes and Engineering Division \\
ERDC & Engineer Research Development Center \\
HABs & Harmful Algal Blooms \\
HCl & hydrochloric acid \\
h & hours \\
LB & Luria Broth \\
MTES & methyltriethoxysilane \\
ml & Mililiter \\
ML & Microlunatus \\
min & minutes \\
OD & Optical Density \\
PAOs & Phosphate Accumulating Organisms \\
PHA & polyhydroxyalkanoates \\
PO & Phosphate \\
ppm & parts-per-million \\
SGM & sol-gel matrix \\
TEOS & tetraethylorthosilicate \\
USACE & U.S. Army Corps of Engineers \\
USEPA & U.S. Environmental Protection Agency \\
WWTPs & Wastewater Treatment Plants \\
\hline
\end{tabular}




\section{Introduction}

\subsection{Background}

Nutrient input into waterways from agriculture runoff, sewage, and other sources is a major cause of water pollution. This process, known as cultural eutrophication, impairs many recreational and commercially important waterways (Chislock et al. 2013). Nutrients such as nitrogen, phosphate, and organic carbon are typically growth-limiting substrates that, when present in high concentrations, allow for unchecked growth of photosynthesizers. Affected sites are not always known, reported, or fully characterized. The availability of these nutrients allows organisms such as cyanobacteria (blue-green algae) to voraciously consume these abundant nutrients, "crowding out" aquatic plants and beneficial green algae, which are important food sources for littoral grazers. Significant cyanobacterial growth may result in reduction in water clarity and light penetration, leading to plant die off, hypoxia, or anoxia.

Another significant and potentially dangerous issue is the proliferation of harmful algal blooms (HABs). Numerous species of cyanobacteria and some true algae (i.e., golden algae) are known to produce toxins that can affect morbidity and mortality of aquatic and terrestrial wildlife and that of humans and domestic animals. Freshwater algal blooms are ubiquitous in the U.S., and without a common reporting mechanism the number of incidences per year is unknown. However, large-profile blooms resulting in toxin release are generally reported and are compiled by various governmental agencies as well as interest groups.

Current approaches to the algal bloom problem have been reactionary, treating the symptoms of entrenched blooms. Unfortunately, algal blooms are a symptom, and the underlying cause is the high nutrient levels which allow the algal blooms to recur. In most cases agricultural or municipal runoff of phosphorous and nitrogen are the primary nutrients released into these waterways, with phosphorous being the predominant growth limiting nutrient (Kortsee et al. 1994). Numerous regulations have been introduced to curb this nutrient input, including reductions in phosphorous-containing fertilizers for municipal and commercial use (summarized at https://www.epa.gov/nutrient-policy-data/what-epa-doing-reduce-nutrientpollution). Public education also has been important in reducing nutrient 
input. For example, the U.S. Environmental Protection Agency (USEPA) has compiled a list of useful educational resources for the individual including webinars, videos, pamphlets, and links to other entities with site specific information (https://www.epa.gov/nutrientpollution/harmful-algal-blooms\#tact). Other means for combating eutrophication have included algaecides and herbicides, and decreasing the photosynthetic ability of aquatic life through shading or additive obscurants like dyes (Chislock et al. 2013). However, in order to prevent recurrence, physical removal of these nutrients from the waterway or watershed is needed.

One approach for phosphate removal is by using phosphate accumulating organisms (PAOs). Some municipal wastewater treatment plants (WWTPs) utilize PAOs as a biological method for removing excess nutrients from their system. Numerous strains of phosphorous hyperaccumulating bacteria have been employed in municipal wastewater treatment plants for nutrient removal. These PAO bacteria accumulate phosphate intracellularly during aerobic respiration as a mechanism for storing phosphate for adenosine triphosphate (ATP) production during anaerobic conditions (Keasling et al. 2000). As the cells proliferate in the aerobic phase of wastewater treatment, they take up phosphate before entering the settling phase, where they are added to the solid sludge material and separated from the treated water (Keasling et al. 2000; Martin et al. 2006). While this is an effective approach in a contained system such as a waste water treatment plant, introduction of such cells to a water body would result in temporary sequestration of phosphate into cells, but not permanent removal from the system. In order to effectively remove phosphate from water bodies where flocculating the cells is not possible, some other method is needed to immobilize cells for removal.

\subsection{Approach}

One potential method of immobilizing cells is using silica sol-gel. Sol-gel is a process by which siliceous molecules in a solution (sol) agglomerate to form a network (gel). The specifics of the sol-gel system used herein are presented in the Methods and Materials Section. Sol-gel encapsulation can be performed at physiologically relevant temperatures and $\mathrm{pH}$ thus making it ideal for preserving biological activity (Gill and Ballesteros 2000). In addition, silica is biologically inert and resistant to many biological degradation mechanisms and the low cost makes it attractive for industrial applications (Yu et al. 2005). Encapsulation in sol-gel is also known to maintain activity of microbial cells much longer than in liquid 
culture. Studies have shown that $E$. coli encapsulated in sol-gel can remain metabolically active for over two months (Mutlu et al. 2015). Previous work has also demonstrated that encapsulation of cells within a sol-gel matrix effectively inhibits cell proliferation (Nassif et al. 2002; Premkumar et al. 2002).

\subsection{Objective}

The goal of this study was to find a way to encapsulate phosphate accumulating bacteria, introduce them into open water systems, allow them to take up phosphate, then remove the cells and phosphate entirely from the water. The results indicate that encapsulated cells are an effective means of sequestering phosphate, however a more robust encapsulation matrix is needed to inhibit cell escape.

\subsection{Scope}

The team hypothesized that sol-gel encapsulation of PAOs would enable efficient removal of phosphate from water through recovery of the introduced cells. To our knowledge this work is the first attempt to immobilize PAOs in an environmentally inert silica matrix (sol-gel) for use as a phosphate biofilter. Repeated application of immobilized cells could allow for large-scale removal of phosphorous, thus reducing the eutrophication effect and limiting the potential for harmful algal blooms. 


\section{Methods and Materials}

\subsection{Growth of pure cultures}

Four bacterial strains were tested for their ability to accumulate phosphate. Microlunatus phosphovorus (ATCC 700054), which is a known phosphate accumulator, Gordonia sp. KTR9 (Indest et al. 2013; Indest et al. 2010), Rhodococcus jostii RHA1 (Indest et al. 2015; Indest et al. 2016), and Nocardioides luteus BAFB (Jung et al. 2002), which are actinomycetes known to produce high concentrations of polyhydroxyalkanoates (PHA) in a process often linked to phosphate accumulation (Seviour et al. 2003). Cells were grown in $50 \mathrm{ml}$ Microlunatus (ML) medium (Nakamura et al. 1995) cultured in $250 \mathrm{ml}$ flasks at $30^{\circ} \mathrm{C}$, shaking for 48 hours (h), pelleted, washed twice in sterile saline, then inoculated into $50 \mathrm{ml}$ fresh ML medium in $250 \mathrm{ml}$ flasks at an optical density (OD) 0.04 at $600 \mathrm{~nm}$, in triplicate, at $30^{\circ} \mathrm{C}$, shaking for $116 \mathrm{~h}$.

\subsection{Monitoring of phosphate uptake}

Phosphate concentrations were measured colorimetrically with a LaMotte Series 1200 colorimeter (LaMotte Company, Chesterton, MD.) as Ophosphate via the ascorbic acid method which utilizes ammonium molybdate and antimony potassium tartrate. Reagents and methods were provided with the LaMotte Series 1200 instrument. Limits of detection were between 0.01-3 ppm. Samples with concentrations above $3 \mathrm{ppm}$ were diluted appropriately in phosphate-free water.

\subsection{Sol-gel encapsulation}

Bacterial cells were encapsulated in a sol-gel matrix (SGM) following the method of Dickson and Ely, 2011 (Dickson and Ely 2011) as described in Table 1. The ratio of tetraethylorthosilicate (TEOS) and methyltriethoxysilane (MTES) was varied to empirically determine the best formulation for highest phosphate uptake and least bacterial cell escape. The acidified precursor consisting of TEOS, MTES, water, and $\mathrm{HCl}$ was stirred for $12 \mathrm{~h}$ prior to encapsulating cells. First trials began by incorporating cells at 108 cells $/ \mathrm{ml}$ into plastic $15 \mathrm{ml}$ test tubes or $1 / 8$ in. sterile silicon tubing, expulsing the material once solidified, and cutting the SGM into $1 / 4-1 / 2$ in. plugs. 
Table 1. Cell encapsulation formulation as determined empirically to preserve physiological activity and reduce escape of cells from the matrix (modified from Dickson and Ely 2011).

\begin{tabular}{|l|l|l|}
\hline Formulation component & Volume $(\mathrm{ml})$ & Notes \\
\hline Sol-gel precursor & & \\
\hline Tetraethylorthosilicate (TEOS) & 6.4 & $\begin{array}{l}\text { Can be scaled up or down } \\
\text { proportionally. }\end{array}$ \\
\cline { 1 - 2 } Methyltriethoxysilane (MTES) & 1.6 & $\begin{array}{l}\text { Final } \mathrm{pH} \text { is } \approx 1.5 . \\
\text { add to sterile flask containing stir bar }\end{array}$ \\
\cline { 1 - 2 } Water & 14.85 h.
\end{tabular}

\subsection{Sol-gel washing trials}

Cells embedded in SGM plugs were placed in sterile saline, methanol, or bleach solution to remove cells from the surface. Methanol was used at $100 \%$ strength for washes of 1,5 , or 10 minutes (min), followed by a five minute sterile water wash. Bleach washes were conducted for one minute each at $8,0.8,0.008$, and $0.0008 \%$ followed by three, one minute water rinses. Sterile water rinses were also performed for five and ten min, twice each. Outgrowth tests were performed in $0.5^{\times}$Luria Broth (LB) with a $0.5 \mathrm{mg} / \mathrm{ml}$ tetrazolium violet indicator. This allowed for the direct observation of metabolism in the pellets by the formation of purple color formation (Figure 1) indicative of substrate reduction via metabolic activity, and escape of cells into the media by turbidity and purple color formation. It is important to note that $0 \%$ escape was never reliably achieved, one of three replicates usually showed outgrowth of cells, consistent with other reports (Nassif et al. 2002). 
Figure 1. Outgrowth test to determine survival and escape of cells from the SGM in which they were embedded. Purple color indicates cell activity.

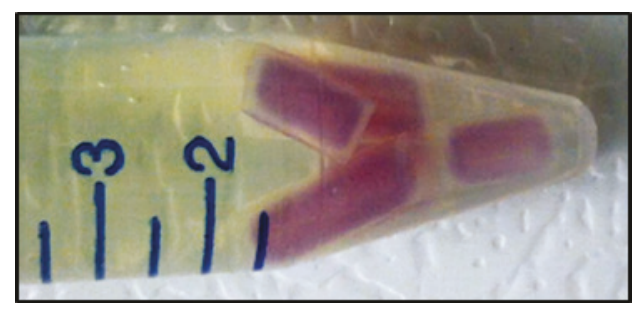

\subsection{Phosphate uptake by cells in SGM}

The first tests were done in 96-well format ( $250 \mu \mathrm{l}$ wells) to determine the physiological activity and survival of the encapsulated cells over time. $M$. phosphovorus cells were added to a SGM and $100 \mu \mathrm{l}$ poured into multiple wells of a 96-well plate. Activity over time (53 days) was assessed by addition of $0.5 \times$ Luria Broth (LB) with $0.5 \mathrm{mg} / \mathrm{ml}$ tetrazolium violet to selected wells which were then monitored for purple color in the SGM. This activity was generally evident within 1-6 h.

Sterile cellulose sponges (autoclaved, 1 in. $\times 0.75$ in. cylinders) were then used as a support matrix for the SGM, as it became evident that the SGM plugs were too fragile to be placed in a water system without support. The sponges were saturated with $8 \mathrm{ml}$ liquid SGM and cells which solidified within the pore spaces of the sponge. The sponge-SGM was then encased in a 3 in. hard-shelled, flow-through sphere (pond or aquarium bioball, purchased from Como, Inc. on Amazon.com(Figure 2), this was not only protective against innumerable physical insults that would be encountered in a waterway, but also allows for easy collection. One bioball was added to each of the $1 \mathrm{~L}$ beakers filled with $600 \mathrm{ml} 0.5 \times \mathrm{LB}$ and phosphate uptake was monitored in the same fashion as the free-living pure culture experiments. Sterile control SGM was also prepared using glycerol in place of cells. 
Figure 2. Protective plastic flow-through encasement for sol-gel embedded cells.

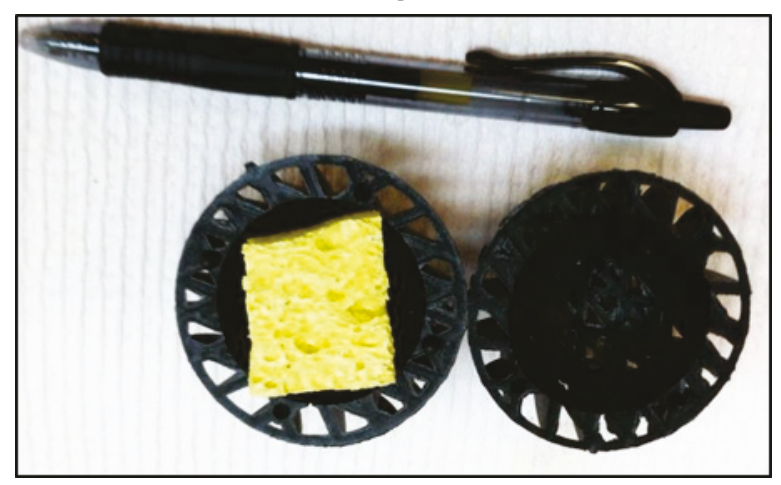




\section{Results and Discussion}

There are many phosphate accumulating organisms that could be used in this study. To date, Microlunatus phosphovorus (ATCC 700054), a bacterial strain that was isolated from activated sludge of a municipal wastewater treatment plant and was determined to hyperaccumulate phosphate (PO4) (Nakamura et al. 1995), and three actinomycete strains, Gordonia sp. KTR9, Rhodococcus jostii RHA1, and Nocardioides luteus BAFB have been tested. Growth (Figure 3) and PO4 uptake (Figure 4) was monitored in free-living pure cultures of these four strains. $M$. phosphovorus was most effective at phosphorous uptake (44\% reduction in the phosphate concentration) with a calculated rate of $3.3 \mathrm{ppm} \mathrm{PO} 4 / \mathrm{h}$ $(1.11 \mathrm{mmol} \mathrm{P} / \mathrm{h}$ ) which is consistent with published values (Santos et al. 1999). Although N. luteus had a faster rate of uptake at $4.6 \mathrm{ppm} \mathrm{PO} 4 / \mathrm{h}$ (1.59 $\mathrm{mmol} \mathrm{P} / \mathrm{h}$ ), it only reduced phosphate concentration by $20 \%$ before releasing some (40 ppm) back into the media at $116 \mathrm{~h}$. Both of these rates, however, are substantial since environmentally relevant conditions approaching $1 \mathrm{ppm}$ are considered eutrophic. Upon switching the cells to an anaerobic environment, the $\mathrm{PO} 4$ was released at a rate of $1.75 \mathrm{ppm}$ $\mathrm{PO} 4 / \mathrm{h}(0.6 \mathrm{mmol} \mathrm{P} / \mathrm{h}$ ) (data not shown), thus allowing control of the uptake and release of $\mathrm{PO}_{4}$ by the bacteria from the water.

Figure 3. Comparative growth of potential phosphate accumulating organisms over $116 \mathrm{~h}$.

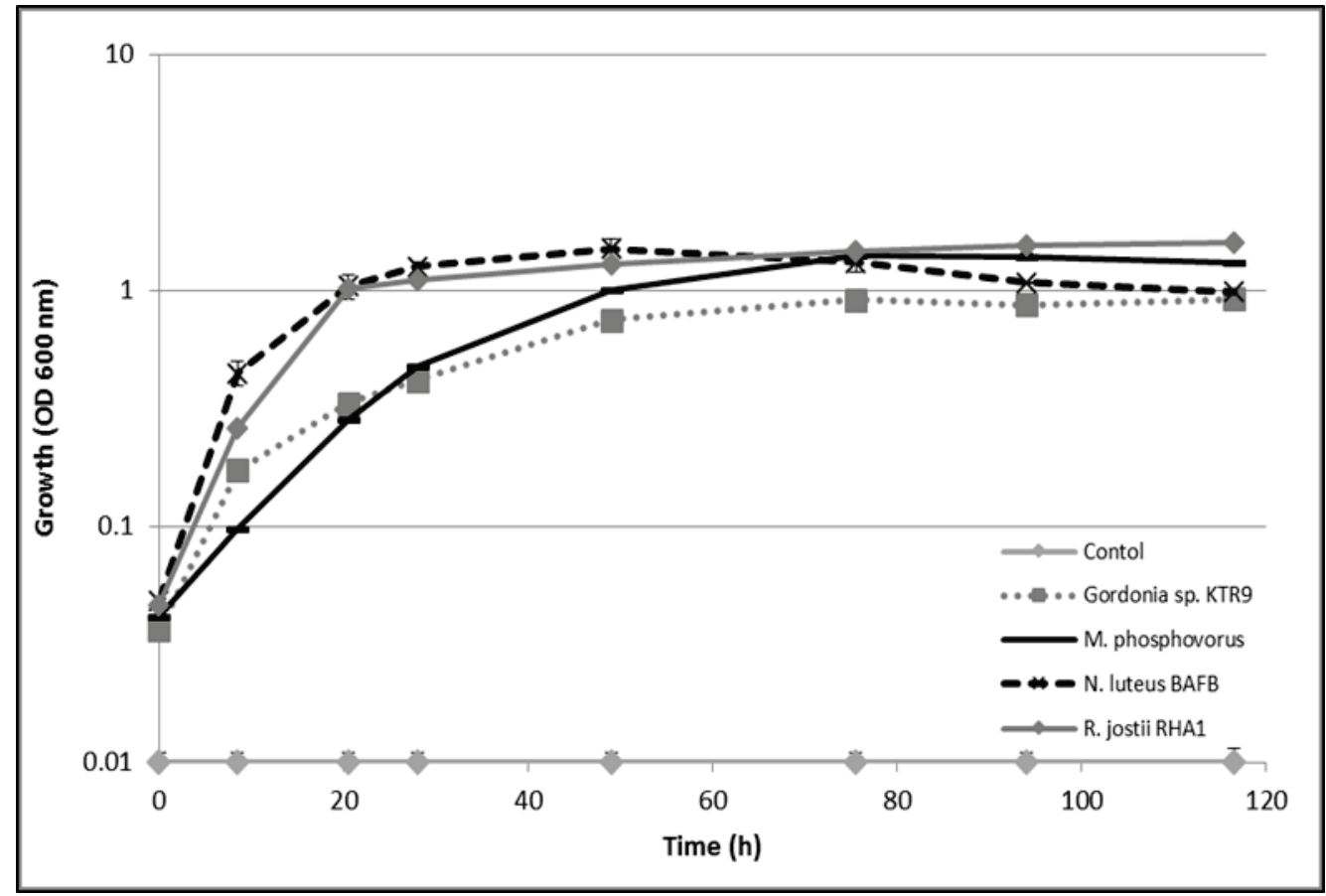


Figure 4. Phosphate uptake from growth medium of putative phosphate accumulating organisms over $116 \mathrm{~h}$.

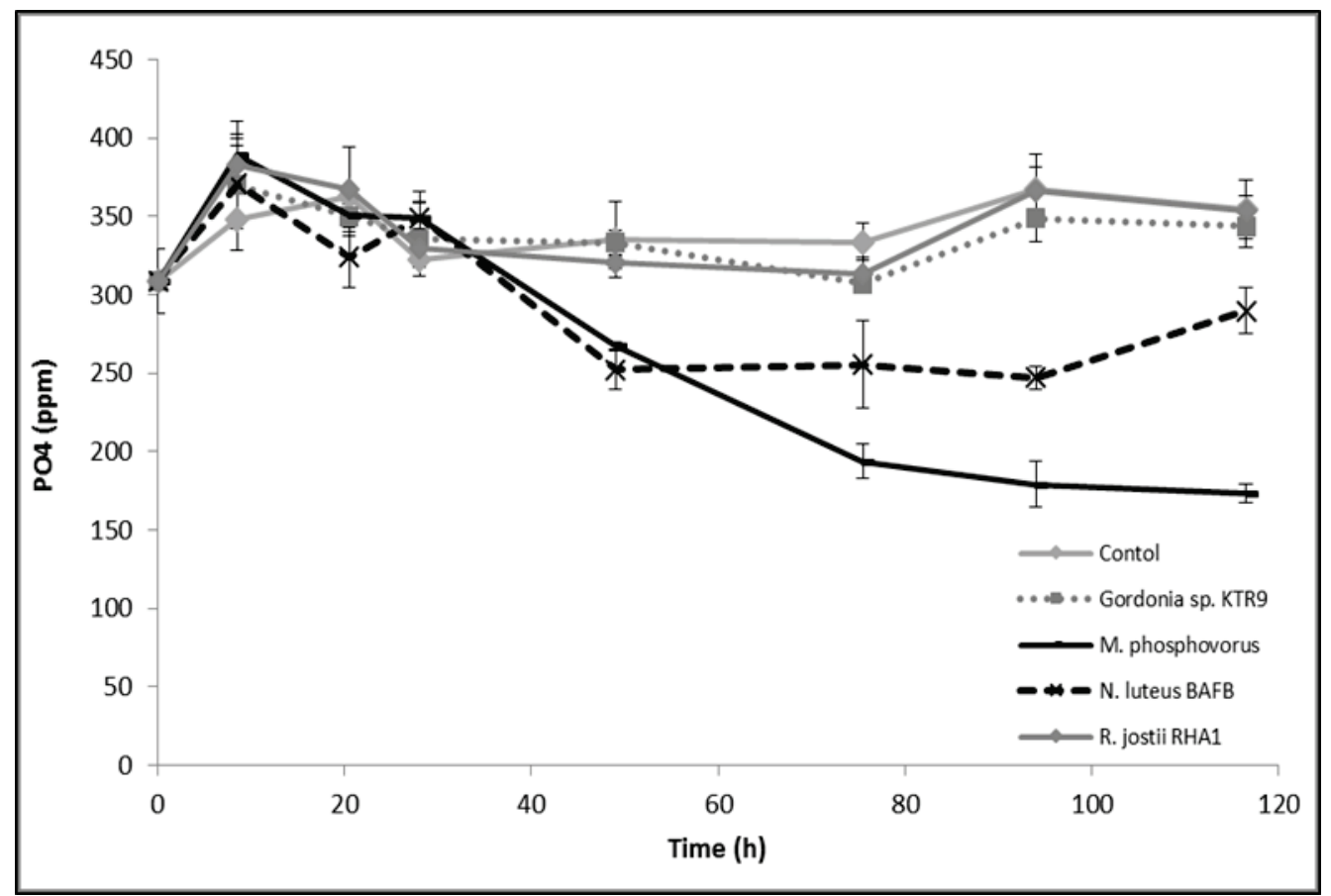

Encapsulation of viable cells within SGM has been demonstrated to improve the long-term stability and metabolic activity of cells when compared to liquid cultures (Saez et al. 2012; Yu et al. 2005). Silica sol-gels can be formulated under biologically compatible temperature and $\mathrm{pH}$ and are highly porous, allowing diffusion of substrates while retaining the encapsulated cells. Briefly, cells were encapsulated in a silica SGM (Table 1) to enable physiological functionality of $M$. phosphovorus over 53 days post encapsulation. M. phosphovorus was still capable of converting the tetrazolium violet indicator to violet, indicating the cells were still active (Figure 5). 
Figure 5. Sol-gel encapsulated $M$.

phosphovorus cells in microplate

wells. Purple color indicates

metabolic activity.

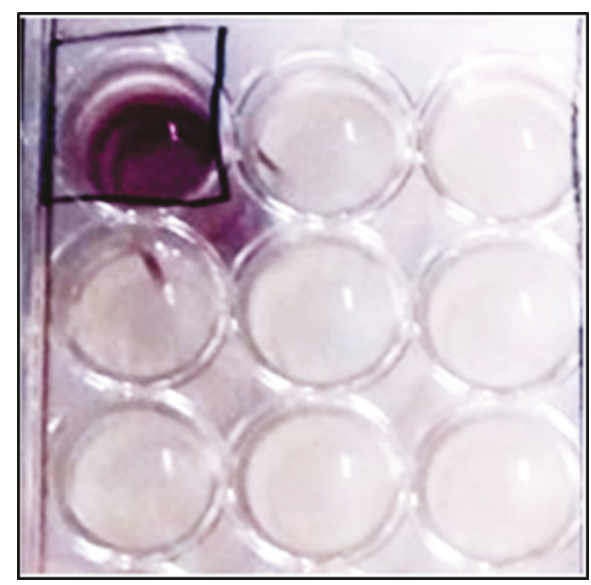

Cell escape was assessed with various methods as simple water washes were found to be unpredictable and limitedly successful. On average, one replicate from each triplicate experimental set exhibited outgrowth of the encapsulated cells into the media. Wash tests were performed with methanol, bleach, and sterile water. Methanol was found to kill the encapsulated bacteria, even at short exposure times. Diluted bleach was found to be somewhat effective at $0.8-0.08 \%$ with a 30 -second exposure for preventing outgrowth, but the embedded cells along the periphery were physiologically inactive (clear margin around SGM pellets with purple throughout the interior) (Figure 1), affecting rates of phosphate uptake significantly (data not shown). Ultimately, it was determined the best method with maximum cell activity was tandem washes in sterile water for ten min each. However, on average, 30\% of the replicates had cells escape/media contamination. The cell escape assays were unpredictable as some triplicate samples were all contaminated, while others had one or no contamination events. No-cell controls were always run and found to be void of contamination, indicating these events were due to cell escape. The frequency of contamination of cells "leaking" into the medium after numerous washes is indicative of the SGM being compromised and allowing cells to be liberated from the encasement. A method to ensure the cells will not "leak" into the environment will be necessary before this technology can be taken to field scale.

Once cells were encapsulated in the sol-gel and sponge matrix, phosphate uptake was monitored. As seen in Figure 6, the replicates were variable in terms of cell escape which resulted in media contamination easily 
visualized by turbidity. However, the encapsulated cells were capable of accumulating phosphate from the medium. One cause of cell escape was thought to be physical breakage of the SGM, even when cast in a sponge.

Figure 6. Phosphorous uptake from ML medium with by sol-gel encapsulated $M$. phosphovorus cells in a sponge encasement. Individual replicates shown due to contamination of the medium with escaped cells. No-cell control SGM in sponge remained sterile (black, dashed line).

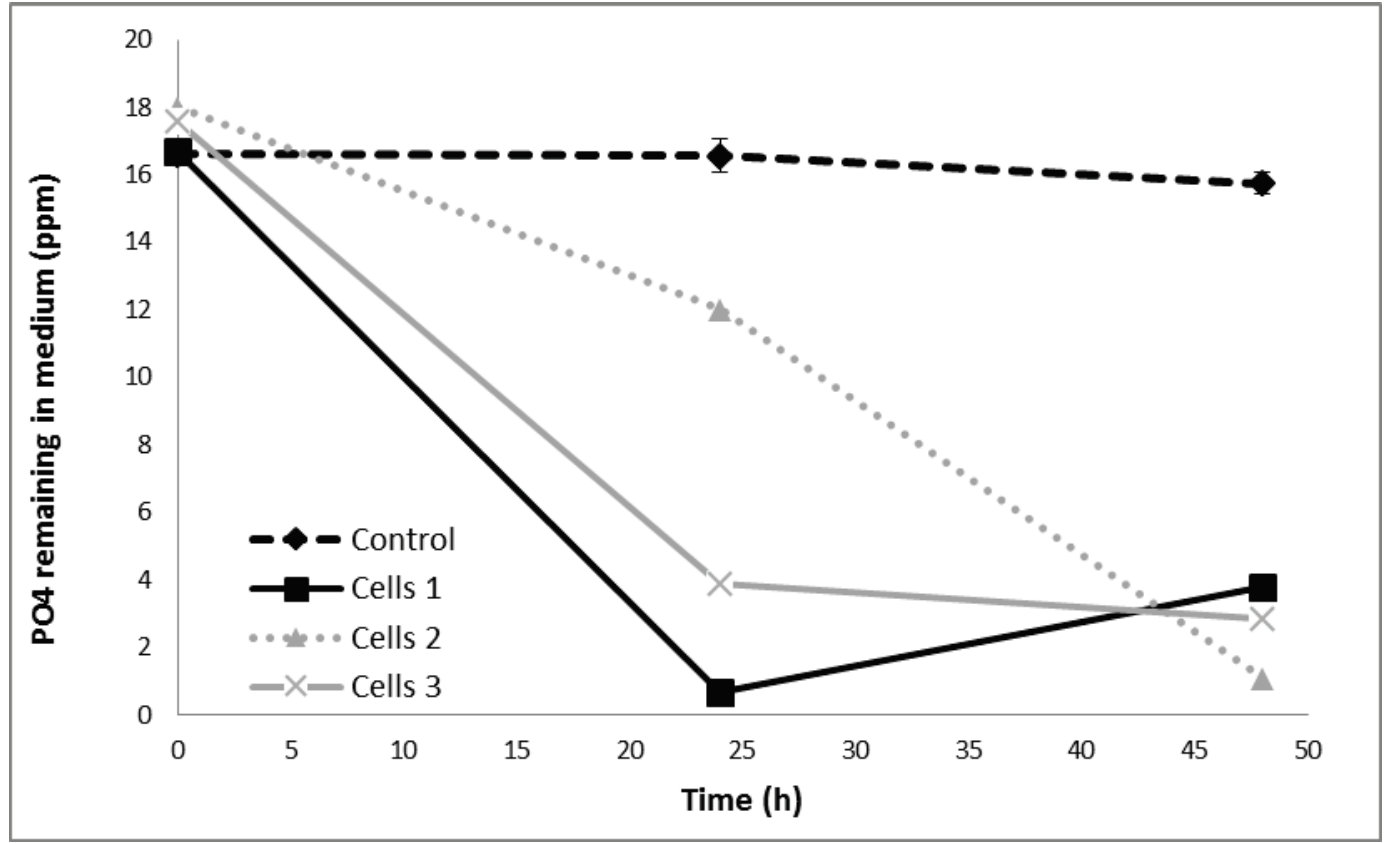

In order to fortify the structural integrity of the SGM, the sponge-SGMcells complex was placed inside a porous, 3 in., hard plastic bioball. Phosphate uptake was again monitored and these trials were more successful, albeit at slower rates than free living cells. This is likely due to the ability of free living cells to replicate while the encapsulated cells did not have enough space within the SGM pores to divide (Nassif et al. 2002; Premkumar et al. 2002). In comparing the total cell density of the free living cells to the SGM cells, the approximate cell number/ml treated volume of the free living cells $\left(8.6 \times 10^{7}\right)$ was 150 times greater than the SGM cells $\left(5.8 \times 10^{5}\right)$. However, a total of $78 \%$ of the $\mathrm{PO}_{4}$ was removed over $120 \mathrm{~h}$, and although the uptake of phosphate from encased cells was about

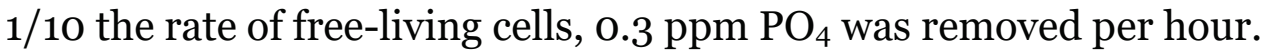
(Figure 7). This rate translates to $80 \mathrm{mmol} \mathrm{P} / \mathrm{g}$ cell dry $\mathrm{wt} / \mathrm{h}$, this is much higher than seen in many biological phosphate removal batch reactors. For example, researchers observed rates of $8 \mathrm{mmol} \mathrm{P} / \mathrm{g}$ suspended solids/h (Nittami et al. 2011), and $0.645 \mathrm{mmol} \mathrm{P/g}$ suspended solids/h (Ong et al. 2013), in sequencing batch reactors with WWTP inoculum under optimal 
conditions, and $3.34 \mathrm{mmol} \mathrm{P} / \mathrm{g}$ cells/h with M. phosphovorus inoculum (Santos et al. 1999). This difference in rate is partially explained by the fact that in the WWTP inoculated reactors P uptake was compared to total suspended solids rather than cell dry weight, underrepresenting the active PAO community (Nittami et al. 2011; Ong et al. 2013). Furthermore, the sequencing batch reactor study with $M$. phosphovorus was conducted in minimal salts medium (Santos et al. 1999), while this study was conducted in half-strength rich medium for one culturing episode or batch.

Figure 7. Phosphorous uptake from $\mathrm{ML}$ medium with no $\mathrm{PO}_{4}$ added by sol-gel encapsulated M. phosphovorus cells in a sponge encasement inside bioballs. No contamination was observed in the encapsulated cells (solid line) or the no-cell control (dashed line).

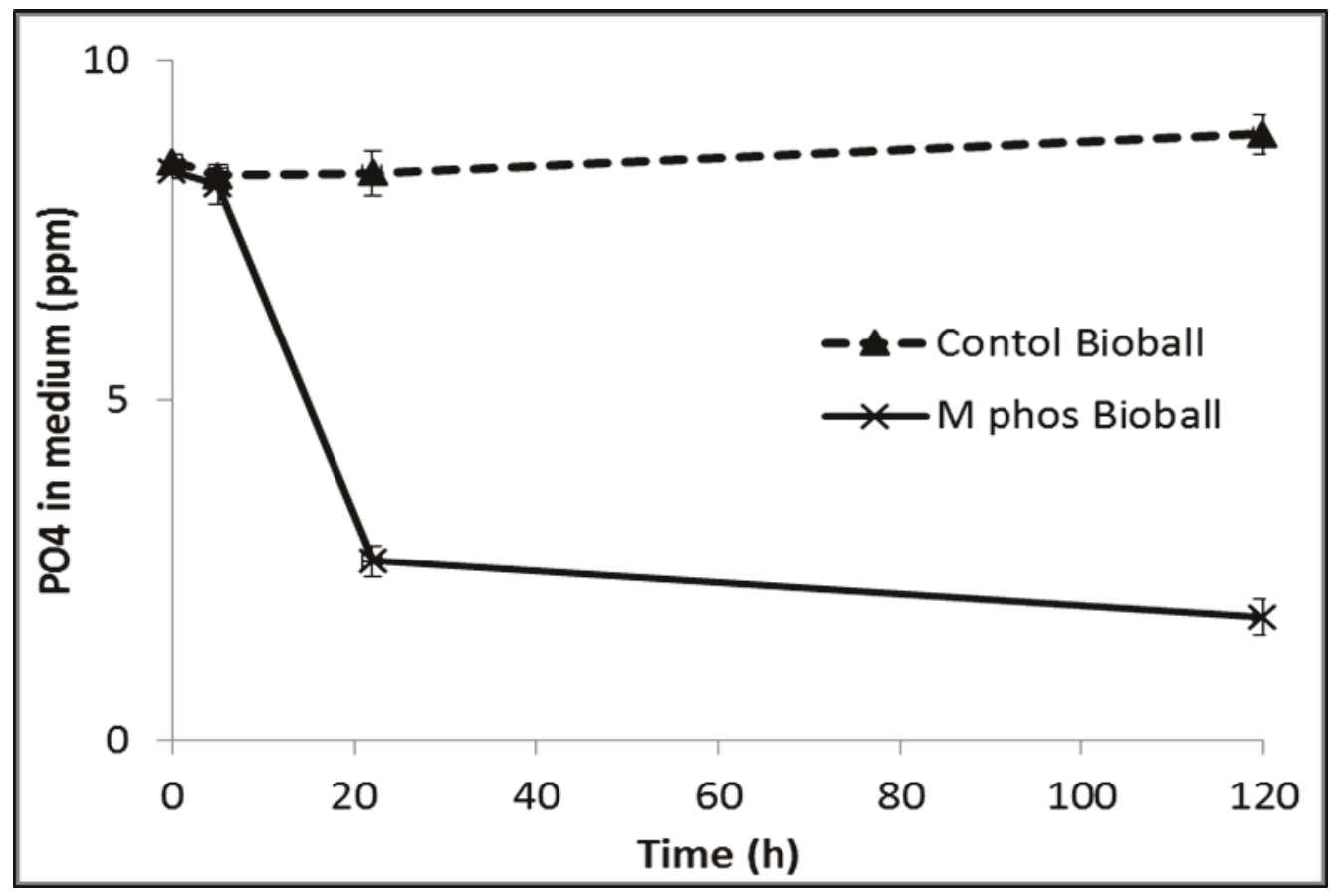




\section{Conclusion}

The number of freshwater sources in the U.S. with documented hypoxia has increased dramatically. This research demonstrates the feasibility of phosphate sequestration by encapsulated cells. In order to use this technology in natural systems numerous hurdles must be overcome. The conceptual design of this effort is a novel method for reduction and removal of phosphorous from freshwater systems in an effort to curb harmful algal blooms and hypoxia events. The goal was to find a way to encapsulate phosphate accumulating bacteria, introduce them into open water systems, allow them to take up phosphate, then remove the cells and phosphate entirely from the water. The results indicate that encapsulated cells are an effective means of sequestering phosphate, however a more robust encapsulation matrix is needed to inhibit cell escape.

The results presented herein represent a starting point for this concept, but the ability to keep the bacteria trapped within the SGM is a major issue that needs critical attention. This concept has potential for very large scale up, low cost, high profile, environmental stewardship as an ecologically friendly, non-invasive solution for phosphate removal with the value added benefit of producing commercially available phosphorous. 


\section{References}

Chislock, M. F., E. Doster, R. A. Zitomer, and A. E. Wilson. 2013. Eutrophication: causes, consequences, and controls in aquatic ecosystems. National Education Knowledge 4(4):10.

Dickson, D.J., and R. L. Ely. 2011. Evaluation of encapsulation stress and the effect of additives on viability and photosynthetic activity of Synechocystis sp. PCC 6803 encapsulated in silica gel. Applied Microbiology and Biotechnology 91:16331646.

Gill, I., and A. Ballesteros. 2000. Bioencapsulation within synthetic polymers (Part 1): Sol-gel encapsulated biologicals. Trends in Biotechnology 18(7):282-296. https://doi.org/10.1016/S0167-7799(00)01457-8.

Indest, K. J., J. O. Eberly, and D. E. Hancock. 2015. Expression and characterization of an $\mathrm{N}$-oxygenase from Rhodococcus jostii RHAI. The Journal of General and Applied Microbiology 61:217-223. https://doi.org/10.2323/igam.61.217.

Indest, K. J., J. O. Eberly, D. E. Hancock, C. M. Jung, M. R. Carr, and G. A. Blakeney. 2016. Rhodococcus jostii RHA1 TadA-homolog deletion mutants accumulate less polyhydroxyalkanoates (PHAs) than the parental strain. The Journal of General and Applied Microbiology 62:213-316. https://doi.org/10.2323/igam.2016.03.002.

Indest, K. J., D. Hancock, C. M. Jung, J. O. Eberly, W. W. Mohn, L. D. Eltis, and F. H. Crocker. 2013. Role of nitrogen limitation in transformation of RDX (hexahydro1,3,5-trinitro-1,3,5-triazine) by Gordonia sp. strain KTR9. Applied and Environmental Microbiology 79:1746-1750.

Indest, K. J., C. M. Jung, H. P. Chen, D. Hancock, C. Florizone, L. D. Eltis, and F. H. Crocker. 2010. Functional characterization of pGKT2, a $182 \mathrm{~kb}$ plasmid containing the $x p L A B$ genes involved in the degradation of RDX by Gordonia sp. KTR9. Applied and Environmental Microbiology 76:6329-6337.

Jung, C. M., C. Broberg, J. Giuliani, L. L. Kirk, and L. F. Hanne. 2002. Characterization of JP-7 jet fuel degradation by the bacterium Nocardioides luteus strain BAFB. Journal of Basic Microbiology 42:127-131. https://doi.org/10.1002/15214028(200205)42:2<127::AID-J0BM127>3.0.C0;2-C.

Keasling, J., S. Van Dien, P. Trelstad, N. Renninger, and K. McMahon. 2000. Application of polyphosphate metabolism to environmental and biotechnological problems. Biochemistry 65:324-331.

Kortsee, G. J. J., K. J. Appledoorn, C. F. C. Bonting, E. W. J. vanNiel, and H. W. vanVeen. 1994. Biology of phosphate-accumulating bacteria involved in enhanced biological phosphorous removal FEMS. Microbiology Reviews 15(2-3):137-153. https://doi.org/10.1111/j.1574-6976.1994.tb00131.x 
Martin, H. G., N. Ivanova,V. Kunin, F. Warnecke, C. W. Barry, A. C. McHardy, C. Yeates, S. He, A. A. Salamov, E. Szeto, E. Dalin, N. H. Putnam, H. J. Shapiro, J. L. Pangilinan, I. Rigoutsos, N. C. Kyrpides, L. L. Blackall, K. D. NcMahon, and P. Hugenholtz. 2006. Metagenomic analysis of two enhanced biological phosphorous removal (EBPR) sludge communities. Nature Biotechnology 24:1263-1269.

Mutlu, B. R., S. Yeom, L. P. Wackett, and A. Aksan. 2015. Modelling and optimization of a bioremediation system utilizing silica gel encapsulated whole-cell biocatalyst Chemical Engineering Journal 259:574-580. http://doi.org/10.1016/i.cej.2014.07.130.

Nakamura, K, A. Hiraishi, Y. Yoshimi, M. Kawaharasaki, K. Masuda, and Y. Kamagata. 1995. Microlunatus phosphovorus gen nov., sp. nov., a new gram-positive polyphosphate-accumulating bacterium isolated from activated sludge. International Journal of Systematic and Evolutionary Microbiology 45:17-22.

Nassif, N., O. Bouvet, M. Noelle Rager, C. Roux, T. Coradin, and J. Livage. 2002 Living bacteria in silica gels. Nature Materials 1:42-44.

Nittami, T., H. Oi, K. Matsumoto, and R. J. Seviour. 2011. Influence of temperature, pH and dissolved oxygen concentration on enhanced biological phosphorus removal under strictly aerobic conditions. New Biotechnology 29:2-8. http://doi.org/10.1016/j.nbt.2011.06.012.

Ong, Y. H., A. S. M. Chua, B. P. Lee, and G. C. Ngoh. 2013 Long-term performance evaluation of EBPR process in tropical climate: start-up, process stability, and the effect of operational $\mathrm{pH}$ and influent C:P ratio. Water Science Technology $67(2): 340-346$.

Premkumar, J. R., E. Sagi, R. Rozen, S. Belkin, A. D. Modestov, and O. Lev. 2002 Fluorescent bacteria encapsulated in sol-gel derived silicate films. Chemistry of Materials 14(6):2676-2686. doi:10.1021/cmo20020v.

Saez, J. M., C. S. Benimeli, and M. J. Amoroso. 2012. Lindane removal by pure and mixed cultures of immobilized actinobacteria. Chemosphere 89(8):982-987. https://doi.org/10.1016/i.chemosphere.2012.06.057.

Santos, M. M., P. C. Lemos, M. A. M. Reis, and H. Santos. 1999. Glucose metabolism and kinetics of phosphorous removal by the fermentative bacterium Microlunatus phosphovorus. Applied and Environmental Microbiology 65:3920-3928.

Seviour, R. J., T. Mino, and M. Onuki. 2003 The microbiology of biological phosphorus removal in activated sludge systems. FEMS Microbiology Reviews 27(1):99-127. https://doi.org/10.1016/S0168-6445(03)00021-4.

Yu, D., J. Volponi, S. Chhabra, C. J. Brinker, A. Mulchandani, and S. K. Singh. 2005. Aqueous sol-gel encapsulation of genetically engineered Moraxella spp. cells for the detection of organophosphates. Biosensors and Bioelectronics 20(7):14331437. https://doi.org/10.1016/j.bios.2004.04.022. 


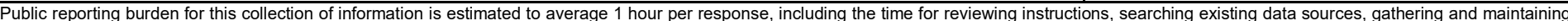

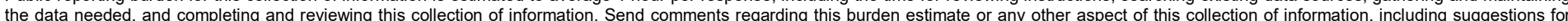

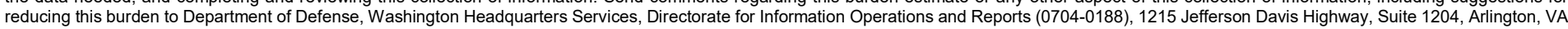

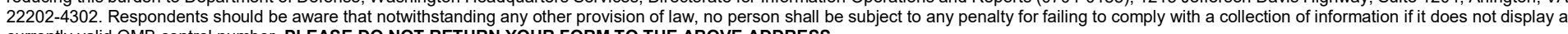
currently valid OMB control number. PLEASE DO NOT RETURN YOUR FORM TO THE ABOVE ADDRESS.

4. TITLE AND SUBTITLE

\begin{abstract}
Biological phosphorous removal from impacted water
\end{abstract}
1. REPORT DATE (DD-MM-YYYY)
August 2018
2. REPORT TYPE
Final report

\section{DATES COVERED (From - To)}

5a. CONTRACT NUMBER

\section{5b. GRANT NUMBER}

5c. PROGRAM ELEMENT NUMBER

\section{5d. PROJECT NUMBER}

454747

Carina M. Jung and Jed O. Eberly

5e. TASK NUMBER

5f. WORK UNIT NUMBER

20D296

\section{PERFORMING ORGANIZATION NAME(S) AND ADDRESS(ES)}

8. PERFORMING ORGANIZATION REPORT NUMBER

U.S. Army Engineer Research and Development Center

Environmental Laboratory

3909 Halls Ferry Road, Vicksburg, MS 39180-6199

\section{SPONSORING / MONITORING AGENCY NAME(S) AND ADDRESS(ES)}

Headquarters, U.S. Army Corps of Engineers

Washington, DC 20314-1000
ERDC/EL TR-18-8

10. SPONSOR/MONITOR'S ACRONYM(S)

11. SPONSOR/MONITOR'S REPORT NUMBER(S)

\section{DISTRIBUTION / AVAILABILITY STATEMENT}

Approved for public release; distribution unlimited.

\section{SUPPLEMENTARY NOTES}

\section{ABSTRACT}

Nutrient input into waterways from agriculture runoff, sewage, and other sources is a major cause of water pollution and cultural eutrophication. Nitrogen and phosphate are growth-limiting nutrients, that when present in high concentrations, allow for unchecked growth of cyanobacteria, resulting in reduced water quality and the potential for proliferation of harmful algal blooms (HABs). Physical removal of these nutrients from waterways is needed. Immobilized phosphorous accumulating bacteria could be used as a phosphate biofilter to absorb and accumulate phosphate from impacted water. The research presented herein demonstrates the immobilization or encapsulation of phosphate accumulating bacteria in a silica sol-gel matrix that can be suspended in a high phosphate water system and then retrieved to collect excess phosphate $\left(\mathrm{PO}_{4}\right)$. Growth and $\mathrm{PO}_{4}$ uptake was monitored in free-living and sol gel immobilized, pure cultures of the phosphate hyperaccumulating bacterium Microlunatus phosphovorus. Phosphate was accumulated at a rate of 3.3 parts-per-million (ppm) $\mathrm{PO}_{4} / \mathrm{h}(1.11 \mathrm{mmol} \mathrm{P} / \mathrm{h})$ and $80 \mathrm{mmol} \mathrm{P} / \mathrm{g}$ cell dry wt/h, respectively. Application of immobilized cells to phosphate impacted waters for uptake and removal of phosphate would allow for large-scale removal of phosphate, thus reducing the eutrophication effect and limiting the potential for HABs.

\begin{tabular}{lll}
\hline 15. SUBJECT TERMS & Water--Pollution & Phosphorus \\
& Nutrient pollution of water & Water--Purification--Biological treatment
\end{tabular}

\section{SECURITY CLASSIFICATION OF:}

a. REPORT

UNCLASSIFIED

b. ABSTRACT
UNCLASSIFIED

c. THIS PAGE

UNCLASSIFIED

17. LIMITATION
OF ABSTRACT

\section{NUMBER OF PAGES}

25 19a. NAME OF RESPONSIBLE PERSON

19b. TELEPHONE NUMBER (include area code) 